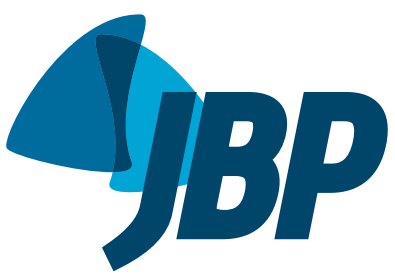

1. Department of Pulmonology, University Hospital of Zurich, Zurich, Switzerland.

2. Department of Pulmonology, Cantonal Hospital of Winterthur, Winterthur, Switzerland.

3. Department of Endocrinology, University Hospital of Zurich, Zurich Switzerland.

a. (iD http://orcid.org/0000-0001-9162-8239

b. (iD http://orcid.org/0000-0003-1377-0496

c. (iD http://orcid.org/0000-0002-8409-5646

d. (iD) http://orcid.org/0000-0003-2080-4439

Submitted: 24 August 2017.

Accepted: 10 April 2018.

Study carried out in the Departmen of Pulmonology, University Hospital of Zurich, Zurich, Switzerland.

\section{Evaluation of bone disease in patients with cystic fibrosis and end-stage lung disease}

\author{
Cécile A. Robinson ${ }^{1, a}$, Markus Hofer ${ }^{2, b}$, Christian Benden ${ }^{1, c}$, Christoph Schmid ${ }^{3, \mathrm{~d}}$
}

\begin{abstract}
Objective: Bone disease is a common comorbidity in patients with cystic fibrosis (CF). We sought to determine risk factors and identify potential biochemical markers for CFrelated bone disease (CFBD) in a unique cohort of CF patients with end-stage lung disease undergoing lung transplantation (LTX) evaluation. Methods: All of the CF patients who were evaluated for LTx at our center between November of 1992 and December of 2010 were included in the study. Clinical data and biochemical markers of bone turnover, as well as bone mineral density (BMD) at the lumbar spine and femoral neck, were evaluated. Spearman's rho and multivariate logistic regression analysis were used. Results: A total of 102 adult CF patients were evaluated. The mean age was 28.1 years (95\% Cl: 26.7-29.5), and the mean body mass index was $17.5 \mathrm{~kg} / \mathrm{m}^{2}$ (95\% Cl: $\left.17.2-18.2\right)$. Mean T-scores were -2.3 and -1.9 at the lumbar spine and femoral neck, respectively, being lower in males than in females (-2.7 vs. -2.0 at the lumbar spine and -2.2 vs. -1.7 at the femoral neck). Overall, $52 \%$ had a T-score of $<-2.5$ at either skeletal site. The homozygous Phe508del genotype was found in $57 \%$ of patients without osteoporosis and in $60 \%$ of those with low BMD. Mean T-scores were not particularly low in patients with severe CFTR mutations. Although the BMI correlated with T-scores at the femoral neck and lumbar spine, serum 25-hydroxyvitamin D and parathyroid hormone levels did not. Conclusions: CFBD is common in CF patients with end-stage lung disease, particularly in males and patients with a low BMI. It appears that CF mutation status does not correlate with CFBD. In addition, it appears that low BMD does not correlate with other risk factors or biochemical parameters. The prevalence of CFBD appears to have recently decreased, most likely reflecting increased efforts at earlier diagnosis and treatment.
\end{abstract}

Keywords: Lung transplantation; Cystic fibrosis; Bone density; Osteoporosis.

\section{INTRODUCTION}

Cystic fibrosis (CF) is a common life-shortening autosomal recessive genetic disorder that affects multiple organs and is caused by mutations in the CFTR gene, which encodes primarily for a chloride ion channel..$^{(1)}$ CF-related comorbidities reduce health-related quality of life and pose an ongoing challenge for patients and treating physicians. The cause of CF-related bone disease (CFBD) is likely multifactorial; CFBD is due to both suboptimal peak bone mass acquisition and increased bone loss during adulthood, affecting up to $20 \%$ of adolescent patients and $55-65 \%$ of patients 45 years of age or older. ${ }^{(2)}$ Known risk factors for the development of CFBD are male sex, low body mass index (BMI), malnutrition, advanced lung disease, and systemic corticosteroid therapy. In fact, several factors contribute to the etiology of CFBD: chronic inflammation/infection, exocrine pancreatic insufficiency/malnutrition, low levels of anabolic hormones (insulin and IGF-I), low levels of sex hormones (estradiol and testosterone), and lack of physical activity. ${ }^{(3-10)}$ In addition, CFTR protein dysfunction has recently been shown to affect bone-forming osteoblasts directly by reducing the production of osteoprotegerin and COX-2 metabolite prostaglandin E2, both of which are mediators of osteogenesis. ${ }^{(11)}$

The objective of the present study was to assess the frequency of CFBD in a unique cohort of adult CF patients with end-stage lung disease evaluated for lung transplantation (LTX) at our center over nearly two decades, in order to gain a deeper understanding of contributing factors to CFBD, identify potential biochemical markers for CFBD, and assess changes in disease severity and therapies over time.

\section{METHODS}

All adult CF patients (18 years of age or older) evaluated for LTx at the University Hospital of Zurich between November of 1992 and December of 2010 were included in the study. Referral and selection of LTX candidates at our center were done in accordance with published International Society for Heart and Lung Transplantation guidelines. (12) Data on CFTR mutation status and patient clinical status (including parameters such as age, sex, height, weight, BMI, percent predicted $\mathrm{FEV}_{1}\left[\mathrm{FEV}_{1} \%\right]$, six-minute walk distance [6MWD], infectious exacerbations 
in the previous year, and CF-related diabetes mellitus [CFRD]) were collected and tabulated. The 5-year survival rate was estimated in accordance with Liou et al. ${ }^{(13)}$ In addition, patient medical records were reviewed for inhaled corticosteroid therapy, systemic corticosteroid therapy, vitamin D supplementation (at least $800 \mathrm{U}$ per day), and bisphosphonate therapy. The following serum levels were measured: C-reactive protein, creatinine, albumin, fasting glucose, hemoglobin A1c, calcium (values being subsequently corrected for albumin by the following formula: measured calcium $-0.025 \times$ albumin +1$)$, phosphate, bone alkaline phosphatase, 25-hydroxyvitamin D (25(OH)D), parathyroid hormone (PTH), osteocalcin, testosterone (in males), and estradiol (in females). In a morning spot urine sample, calciumto-creatinine and deoxypyridinoline-to-creatinine ratios were determined. Creatinine was also measured in a 24-h urine collection in order to estimate skeletal muscle mass and glomerular filtration rate (GFR). The Cockcroft and Gault equation was used in order to calculate GFR, as proposed by Soulsby et al. ${ }^{(14)}$ The relative time to first evaluation for LTX was calculated and used for multivariate regression analysis. In addition, bone mineral density (BMD) was measured by dualenergy X-ray absorptiometry (DXA) and quantitative digital radiography (Hologic $₫$ DXA System; Hologic, Inc., Marlborough, MA, USA) at the femoral neck and lumbar spine, respectively, T-scores being calculated for both sites. Osteoporosis was defined in accordance with the World Health Organization BMD criteria as a T-score of $\leq-2.5$, whereas osteopenia was defined as a T-score between -1.0 and -2.5 . $^{(15)}$

Clinical and biochemical data are reported as means and $95 \%$ confidence intervals. The following groups of patients were evaluated: 1 ) females and males; 2) patients with osteoporosis (i.e., those with a T-score of $\leq-2.5$ at either skeletal site) and patients without osteoporosis; and 3) patients evaluated earlier in the study period and patients evaluated later in the study period. For group comparisons, the Mann-Whitney test and the Kruskal-Wallis test were used, Fisher's exact test or the chi-square test being used for categorical variables. Continuous variables were correlated by using Spearman's rho. Univariate and multivariate logistic regression models were used in order to analyze osteoporosis (overall osteoporosis, lumbar spine osteoporosis, and femoral neck osteoporosis) and sex, as well as the relative time to evaluation for LTX and clinical parameters (BMI, FEV $\%$, 6MWD, CFRD, 25(OH) $\mathrm{D}$ levels, phosphate levels, calcium levels, and protein levels). All statistical analyses were performed with the IBM SPSS Statistics software package, version 23.0 (IBM Corporation, Armonk, NY, USA). For all analyses, values of $p<0.05$ were considered significant. The Research Ethics Committee of the Canton of Zurich approved this retrospective study (Protocol no. EK-1593).

\section{RESULTS}

A total of 102 adult CF lung transplant candidates were included in the present study. The clinical characteristics of the study patients are shown in Table 1.
BMD values as measured by DXA were available for all patients. Of those, $8(8 \%)$ showed normal bone mass, 41 (40\%) had osteopenia, and 53 (52\%) had osteoporosis at either skeletal site. Mean T-scores at the femoral neck and lumbar spine were -1.9 (95\% CI: 1.73 to -2.10$)$ and -2.3 (95\% CI: -2.09 to -2.55$)$, respectively, being lower in males than in females ( $p$ $=0.007$ and $p=0.004$, respectively; Figure 1 ).

There were no differences in clinical parameters (or medication use) between males and females, the exception being height and weight (Table 1). The mean BMI was lower in patients with osteoporosis than in those without $\left(17.4 \mathrm{~kg} / \mathrm{m}^{2}\right.$ vs. $18.1 \mathrm{~kg} / \mathrm{m}^{2} ; \mathrm{p}=0.007$; Table 2). No differences were found between the subgroups of patients with and without osteoporosis regarding $\mathrm{FEV}_{1} \%, 6 \mathrm{MWD}$, frequency of $\mathrm{CF}$ exacerbations in the previous year, use of medications, presence of exocrine pancreatic insufficiency, or CFRD (Table 2).

Table 3 shows biochemical parameters in all CF patients included in the study, by osteoporosis status (i.e., with or without osteoporosis). Although there were no significant differences between the two groups of patients, those with low T-scores (defining osteoporosis in the elderly) were more likely to have an increased calcium-to-creatinine ratio in a fasting spot urine sample $(p=0.04)$. In particular, there was no difference in serum levels of calcium, phosphate, $25(\mathrm{OH}) \mathrm{D}$, or PTH. Borderline high (albumin-corrected) calcium levels were found in 8 patients, and PTH levels $>65 \mathrm{ng} / \mathrm{L}$ (indicating secondary hyperparathyroidism in patients with low-normal serum calcium levels) were found in 11 (Table 3). Correlations of PTH levels with $25(\mathrm{OH}) \mathrm{D}$ and calcium levels are shown in Figure 2. Although PTH levels correlated significantly with (albumin-corrected) calcium levels (Spearman's rho: $-0.40 ; p<0.001)$, they did not correlate with $25(\mathrm{OH}) \mathrm{D}$ levels, age, creatinine levels, GFR, albumin levels, urinary calcium-to-creatinine ratio, urinary deoxypyridinoline-to-creatinine ratio, or 24-h urinary creatinine levels. Serum levels of PTH were not increased in a substantial number of patients with decreased serum levels of $25(\mathrm{OH})$ D. In addition, serum PTH levels were not associated with increased bone resorption markers or low BMD.

As can be seen in Table 2, 50 patients (49\%) were receiving vitamin $D$ supplementation $(4,000$ IU plus multivitamin supplementation including vitamins $A$, $D, E$, and $K)$, and 11 patients (11\%) were receiving bisphosphonate therapy; 48 (47\%) used inhaled corticosteroids on a regular basis, and 33 (32\%) were on long-term systemic corticosteroid therapy. Patients using systemic corticosteroids were more likely to have low BMD ( $p=0.023)$. A low BMI was found to correlate with low BMD ( $p=0.004)$. Of the 102 patients included in the study, 97 (95\%) had exocrine pancreatic insufficiency and were receiving pancreatic enzyme supplementation (the dose of which varied depending on their diet).

CF mutation status was known in 84 patients. Of those, $51(61 \%)$ had a severe mutation (Table 2). 

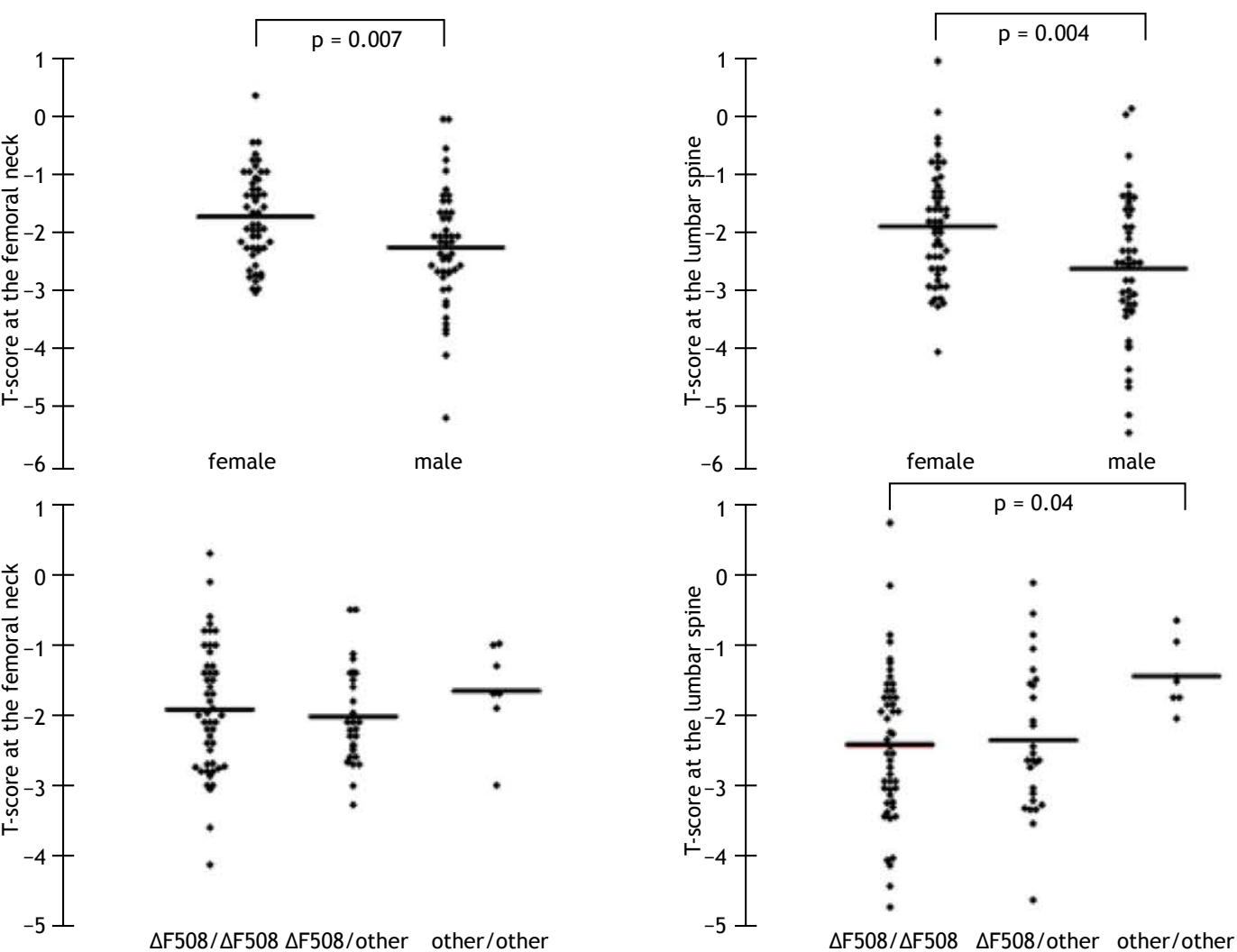

Figure 1. T-scores at the femoral neck and lumbar spine, by gender and CFTR gene mutation.

Table 1. Clinical characteristics of the cystic fibrosis patients included in the study. ${ }^{a}$

\begin{tabular}{|c|c|c|c|c|}
\hline Characteristic & $\begin{array}{l}\text { Total sample } \\
\begin{array}{c}N=102 \\
(100 \%)\end{array}\end{array}$ & $\begin{array}{c}\text { Female CF } \\
\text { patients } \\
\mathrm{n}=53(52 \%)\end{array}$ & $\begin{array}{l}\text { Male CF patients } \\
n=49(48 \%)\end{array}$ & $\mathbf{p}$ \\
\hline Age, years & $28.1(26.7-29.5)$ & $27.5(25.7-29.3)$ & $28.8(26.6-31.0)$ & \\
\hline Height, cm & $166(164-167)$ & $161(160-164)$ & $170(168-172)$ & $<0.0001$ \\
\hline Weight, kg & $48(47-50)$ & $47(45-49)$ & $50(48-53)$ & 0.01 \\
\hline $\mathrm{BMI}, \mathrm{kg} / \mathrm{m}^{2}$ & $17.5(17.2-18.2)$ & $18.0(17.2-18.9)$ & $17.4(16.8-18.0)$ & \\
\hline $\mathrm{FEV}_{1}, \%$ predicted & $25(24-27)$ & $27(24-29)$ & $24(22-26)$ & \\
\hline Relative time to first evaluation, years & $9.9(8.9-10.9)$ & $10.4(9.0-11.8)$ & $9.3(8.0-10.7)$ & \\
\hline Estimated 5-year survival, \% & $30(28-33)$ & $31(27-35)$ & $30(28-33)$ & \\
\hline Osteoporosis, no/yes, n(\%) & $49 / 53(48 / 52)$ & $30 / 23(57 / 43)$ & $19 / 30(39 / 61)$ & \\
\hline T-score at the lumbar spine & $\begin{array}{c}-2.3(-2.1 \text { to } \\
-2.6)\end{array}$ & $\begin{array}{c}-1.99(-1.72 \text { to } \\
-2.26)\end{array}$ & $\begin{array}{c}-2.70(-2.34 \text { to } \\
-3.05)\end{array}$ & 0.004 \\
\hline \multicolumn{5}{|l|}{$\mathrm{BMD}$ at the lumbar spine } \\
\hline Normal (T-scores > -1), n (\%) & $11(11)$ & $11(21)$ & $8(16)$ & \\
\hline $\begin{array}{l}\text { Osteopenia (T-scores ranging from }-1 \text { to }-2.4) \text {, } \\
n(\%)\end{array}$ & $41(42)$ & $30(59)$ & $25(49)$ & \\
\hline Osteoporosis (T-scores of $\leq-2.5), n(\%)$ & $45(47)$ & $10(20)$ & $18(35)$ & \\
\hline T-score at the femoral neck & $\begin{array}{c}-1.9 \\
(-1.7 \text { to }-2.1)\end{array}$ & $\begin{array}{c}-1.67 \\
(-1.45 \text { to }-1.89)\end{array}$ & $\begin{array}{c}-2.19 \\
(-1.9 \text { to }-2.48)\end{array}$ & 0.007 \\
\hline \multicolumn{5}{|l|}{ BMD at the femoral neck } \\
\hline $\begin{array}{l}\text { Osteopenia (T-scores ranging from }-1 \text { to }-2.4) \text {, } \\
\mathrm{n}(\%)\end{array}$ & $54(55)$ & $25(49)$ & $16(35)$ & \\
\hline Osteoporosis (T-scores of $\leq-2.5), n(\%)$ & $28(29)$ & $18(35)$ & 27 (59) & \\
\hline
\end{tabular}

CF: cystic fibrosis; BMI: body mass index; and BMD: bone mineral density. ${ }^{a}$ Values expressed as mean (95\% CI), except where otherwise indicated. 
Table 2. Clinical characteristics of the cystic fibrosis included in the study, by osteoporosis status (i.e., with or without osteoporosis) and era of evaluation (i.e., earlier or later in the study period). ${ }^{\mathrm{a}}$

\begin{tabular}{|c|c|c|c|c|c|}
\hline \multirow[t]{2}{*}{ Characteristic } & \multicolumn{2}{|c|}{ Osteoporosis } & \multicolumn{2}{|c|}{ Era of evaluation } & \multirow[t]{2}{*}{ p } \\
\hline & $\begin{array}{c}\text { Without } \\
n=49(48 \%)\end{array}$ & $\begin{aligned} & \text { With } \\
n= & 53(52 \%)\end{aligned}$ & $\begin{array}{l}\text { First } 51 \\
\text { patients }\end{array}$ & $\begin{array}{l}\text { Last } 51 \\
\text { patients }\end{array}$ & \\
\hline T-score at the lumbar spine & $\begin{array}{c}-1.52 \\
(-1.31 \text { to }-1.72)\end{array}$ & $\begin{array}{c}-3.15-2.90 \text { to } \\
-3.4)\end{array}$ & $\begin{array}{c}-2.56 \\
(-2.18 \text { to }-2.94)\end{array}$ & $\begin{array}{c}-2.11 \\
(-1.85 \text { to }-2.38)\end{array}$ & 0.02 \\
\hline T-score at the femoral neck & $\begin{array}{c}-1.29 \\
(-1.11 \text { to }-1.47)\end{array}$ & $\begin{array}{c}-2.55 \\
(-2.35 \text { to }-2.75)\end{array}$ & $\begin{array}{c}-2.29 \\
(-2.01 \text { to }-2.57)\end{array}$ & $\begin{array}{c}-1.58 \\
(-1.37 \text { to }-1.79)\end{array}$ & $<0.0001$ \\
\hline $\begin{array}{l}\text { Relative time to first evaluation, } \\
\text { years }\end{array}$ & $\begin{array}{c}11.7 \\
(10.3-13.0)\end{array}$ & $\begin{array}{c}8.2 \\
(7.0-9.5)\end{array}$ & $\begin{array}{c}5.7 \\
(4.8-6.5)\end{array}$ & $\begin{array}{c}14.1 \\
(13.5-14.7)\end{array}$ & \\
\hline Sex, F/M, n (\%) & $\begin{array}{c}30 / 19 \\
(61 / 39)\end{array}$ & $\begin{array}{l}23 / 30 \\
(43 / 57)\end{array}$ & $\begin{array}{c}24 / 27 \\
(47 / 53)\end{array}$ & $\begin{array}{l}29 / 22 \\
(57 / 43)\end{array}$ & \\
\hline Age, years & $\begin{array}{c}27.7 \\
(25.6-29.9)\end{array}$ & $\begin{array}{c}28.4 \\
(26.6-30.3)\end{array}$ & $\begin{array}{c}28.0 \\
(26.1-29.8)\end{array}$ & $\begin{array}{c}28.3 \\
(26.2-30.4)\end{array}$ & \\
\hline $\mathrm{BMI}, \mathrm{kg} / \mathrm{m}^{2}$ & $\begin{array}{c}18.1 \\
(17.6-18.6)\end{array}$ & $\begin{array}{c}17.4 \\
(16.5-18.3)\end{array}$ & $\begin{array}{c}17.0 \\
(16.6-17.4)\end{array}$ & $\begin{array}{c}18.5 \\
(17.6-19.4)\end{array}$ & 0.001 \\
\hline $\mathrm{FEV}_{1}, \%$ predicted & $\begin{array}{c}26 \\
(24-28)\end{array}$ & $\begin{array}{c}25 \\
(22-27)\end{array}$ & $\begin{array}{c}0.9 \\
(0.7-0.9)\end{array}$ & $\begin{array}{c}1.2 \\
(0.5-1.8)\end{array}$ & \\
\hline 6MWD, m & $\begin{array}{c}367 \\
(336-398)\end{array}$ & $\begin{array}{c}339 \\
(301-378)\end{array}$ & $\begin{array}{c}332 \\
(300-366)\end{array}$ & $\begin{array}{c}376 \\
(340-413)\end{array}$ & 0.04 \\
\hline $\begin{array}{l}\text { CF exacerbation in the previous } \\
\text { year }\end{array}$ & $4.4(4.2-4.7)$ & $4.3(3.9-4.6)$ & $4.3(4.0-4.5)$ & $4.5(4.1-4.8)$ & \\
\hline Prednisone use, no/yes, n (\%) & $37 / 12(76 / 23)$ & $29 / 21^{b}(58 / 42)$ & $32 / 16^{\mathrm{b}}(63 / 37)$ & $34 / 17(67 / 33)$ & \\
\hline $\begin{array}{l}\text { Inhaled corticosteroid use, no/ } \\
\text { yes, n (\%) }\end{array}$ & $28 / 21(57 / 43)$ & $23 / 27^{\mathrm{b}}(46 / 54)$ & $23 / 25^{\mathrm{b}}(45 / 55)$ & $28 / 23(55 / 45)$ & \\
\hline $\begin{array}{l}\text { Vitamin D supplementation, no/ } \\
\text { yes, } n(\%)\end{array}$ & $22 / 27(45 / 55)$ & $27 / 23^{\mathrm{b}}(54 / 46)$ & $33 / 15^{\mathrm{b}}(65 / 35)$ & $16 / 35(31 / 69)$ & $<0.001$ \\
\hline $\begin{array}{l}\text { Bisphosphonate therapy, no/ } \\
\text { yes, } n(\%)\end{array}$ & $46 / 3(94 / 6)$ & $42 / 8^{b}(84 / 16)$ & $46 / 2^{\mathrm{b}}(90 / 10)$ & $42 / 9(82 / 18)$ & 0.05 \\
\hline CFRD, no/yes, n (\%) & $12 / 37(24 / 76)$ & $22 / 31(42 / 58)$ & $23 / 28(45 / 55)$ & $11 / 40(22 / 78)$ & \\
\hline $\begin{array}{l}\text { Exocrine pancreatic } \\
\text { insufficiency, no/yes, n (\%) }\end{array}$ & $46 / 3(94 / 6)$ & $51 / 2(96 / 4)$ & $47 / 4(92 / 8)$ & $50 / 1(98 / 2)$ & \\
\hline \multicolumn{6}{|l|}{ CFTR genotype, $\mathrm{n}(\%)^{\mathrm{c}}$} \\
\hline Unknown & $7(14)$ & $11(21)$ & $15(29)$ & $3(6)$ & \\
\hline Known & $42(86)$ & $42(79)$ & $36(71)$ & $48(94)$ & \\
\hline Severe/Severe & $25(60)$ & $26(62)$ & $20(55)$ & $29(60)$ & \\
\hline Severe/Mild & $11(26)$ & $15(36)$ & $15(42)$ & $13(27)$ & \\
\hline Mild/Mild & $6(14)$ & $1(2)$ & $1(3)$ & $6(13)$ & \\
\hline Estimated 5-year survival, \% ${ }^{\mathrm{d}}$ & $30(27-34)$ & $30(27-34)$ & $31(27-35)$ & $30(26-33)$ & \\
\hline
\end{tabular}

BMI: body mass index; 6MWD: six-minute walk distance; CF: cystic fibrosis; CFRD: CF-related diabetes mellitus; and CFTR: cystic fibrosis transmembrane conductance regulator. avalues expressed as mean (95\% CI), except where otherwise indicated. bMedication unknown in 3 patients. 'Severe: class I-III mutations; and mild: class IV-VI mutations. ${ }^{\mathrm{d}}$ In accordance with Liou et al. ${ }^{(13)}$

With regard to CFTR mutation status (severe vs. mild mutations), no differences were found between the two regarding BMD.

As can be seen in Table 2, comparisons were made between CF patients evaluated for LTX in the 19922003 period $(n=51)$ and those evaluated for LTx in the 2004-2010 period $(n=51)$. Osteoporosis was much more common in the earlier era $(n=34 ; 65 \%$ vs. $\mathrm{n}=19 ; 36.5 \%)$, whereas osteopenia was more common in the later era ( $n=14 ; 27 \%$ vs. $n=27$; $52 \%$ ). In addition, the 51 patients evaluated in the later era had a higher BMI $\left(18.5 \mathrm{~kg} / \mathrm{m}^{2}\right.$ vs. $17 \mathrm{~kg} / \mathrm{m}^{2}$; $\mathrm{p}=0.007)$. Furthermore, vitamin $\mathrm{D}$ supplementation and bisphosphonate therapy were more common in the later era than in the earlier era $(n=35 ; 67 \%$ vs. $n=15 ; 29 \%$ and $n=9 ; 17.3 \%$ vs. $n=2 ; 4 \%$, respectively). Moreover, CFRD was more frequently diagnosed (and subsequently treated with insulin) in the later era ( $n=40 ; 77 \%$ vs. $n=28 ; 54 \%$ ).

In the multivariate analysis, the overall prevalence of osteoporosis was lower in the later era $(\mathrm{OR}=0.88$; 95\% CI: $0.80-0.96 ; \mathrm{p}=0.005)$, as was the prevalence of osteoporosis at the femoral neck (OR $=0.76 ; 95 \%$ $\mathrm{CI}: 0.63-0.92 ; \mathrm{p}=0.05)$. A high $\mathrm{FEV}_{1} \%$ was found to be a negative predictor of femoral neck osteoporosis $(\mathrm{OR}=0.88 ; 95 \% \mathrm{CI}: 0.79-0.98 ; \mathrm{p}=0.03)$. Males were more likely to have osteoporosis at the lumbar spine than were females $(\mathrm{OR}=2.68 ; 95 \% \mathrm{CI}: 1.13-6.35 ; \mathrm{p}$ $=0.03)$. A low BMI was found to be a positive predictor of osteoporosis (OR $=0.75 ; 95 \% \mathrm{CI}$ : 0.58-0.98; $\mathrm{p}$ $=0.003)$ and lumbar spine osteoporosis (OR $=0.70$; 95\% CI: 0.54-0.91; $p=0.007)$. Mean T-scores at the 
Table 3. Biochemical parameters in the cystic fibrosis patients included in the study, by osteoporosis status (i.e., with or without osteoporosis). ${ }^{\text {a }}$

\begin{tabular}{|c|c|c|c|c|c|}
\hline Parameter & All & $\begin{array}{c}\text { Without } \\
\text { osteoporosis }\end{array}$ & $\begin{array}{c}\text { With } \\
\text { osteoporosis }\end{array}$ & p & $\begin{array}{l}\text { Normal } \\
\text { range }\end{array}$ \\
\hline CRP, mg/L & $33(26-40)$ & $31(19-44)$ & $34(25-42)$ & & $<5$ \\
\hline Creatinine, $\mu \mathrm{mol} / \mathrm{L}$ & $67(64-70)$ & $65(61-68)$ & $69(65-73)$ & & $62-106$ \\
\hline GFR, $\mathrm{mL} / \mathrm{min} / 1.73 \mathrm{~km}^{2}$ & $92(88-96)$ & $95(90-100)$ & $90(84-96)$ & & \\
\hline Albumin, $g / L$ & $36(35-38)$ & $37(35-40)$ & $35(34-37)$ & & $40-49$ \\
\hline $\mathrm{HbA1c}, \%$ & $6.7(6.5-6.9)$ & $6.7(6.4-6.9)$ & $6.6(6.3-7.0)$ & & 4.8-5.9 \\
\hline Fasting glucose, $\mathrm{mmol} / \mathrm{L}$ & $6.5(5.8-7.2)$ & $6.6(5.6-6.7)$ & $6.8(5.6-8.0)$ & & $<5.6$ \\
\hline Calcium (albumin-corrected), $\mathrm{mmol} / \mathrm{L}$ & $2.36(2.32-2.40)$ & $2.33(2.26-2.40)$ & $2.39(2.36-2.43)$ & & $2.09-2.54$ \\
\hline Phosphate, $\mathrm{mmol} / \mathrm{L}$ & $1.05(1.01-1.10)$ & $1.02(0.95-1.09)$ & $1.08(1.02-1.14)$ & & $0.87-1.45$ \\
\hline Alkaline phosphatase, $\mathrm{U} / \mathrm{L}$ & $139(119-158)$ & $138(11-164)$ & $140(11-168)$ & & $40-129$ \\
\hline Bone alkaline phosphatase, $\mu \mathrm{g} / \mathrm{L}(\mathrm{n}=83)$ & $15.7(13.7-17.7)$ & $15.1(12.7-17.6)$ & $16.4(13.1-19.6)$ & & $3.7-21.1$ \\
\hline $25(\mathrm{OH}) \mathrm{D}, \mu \mathrm{g} / \mathrm{L}(\mathrm{n}=85)$ & $21(18-23)$ & $21(18-25)$ & $20(16-24)$ & & $10-42$ \\
\hline $25(\mathrm{OH}) \mathrm{D}<30 \mu \mathrm{g} / \mathrm{L}$, no/yes, $\mathrm{n}(\%)$ & $22 / 63(26 / 74)$ & $11 / 34(24 / 76)$ & $11 / 29(28 / 72)$ & & \\
\hline PTH, ng/L $(n=84)$ & $50(46-61)$ & $50(40-59)$ & $51(31-71)$ & & $15-65$ \\
\hline PTH > 65 ng/L, no/yes, n (\%) & $73 / 11(87 / 13)$ & $40 / 4(91 / 9)$ & $33 / 7(83 / 17)$ & & \\
\hline Osteocalcin, $n g / L(n=30)$ & $4.3(3.5-5.0)$ & $4.6(3.3-5.9)$ & $4.0(3.1-5.0)$ & & $2.4-10.0$ \\
\hline Testosterone (in males), $\mathrm{nmol} / \mathrm{L}(\mathrm{n}=34)$ & $13.6(11.3-15.9)$ & $15.8(12.3-19.3)$ & $11.7(8.6-14.8)$ & & $7.57-31.4$ \\
\hline Estradiol (in females), pmol/L $(\mathrm{n}=39)$ & $189(129-250)$ & $189(95-283)$ & $190(110-270)$ & & \\
\hline Urinary calcium/creatinine $(n=78)$ & $0.5(0.5-0.6)$ & $0.50(0.39-0.61)$ & $0.55(0.45-0.65)$ & & $0.1-0.5$ \\
\hline Urinary calcium/creatinine $>0.5$, no/yes, $\mathrm{n}(\%)$ & $46 / 32(59 / 41)$ & $20 / 16(56 / 44)$ & $12 / 29(29 / 71)$ & 0.04 & \\
\hline Urinary deoxypyridinoline/creatinine $(n=85)$ & $8.0(7.0-9.0)$ & $7.7(6.3-9.1)$ & $8.4(6.8-9.9)$ & & $2.5-5.0$ \\
\hline $\begin{array}{l}\text { Urinary deoxypyridinoline/creatinine }>5.0 \text {, } \\
\text { no/yes, } n(\%)\end{array}$ & $23 / 62(27 / 73)$ & $11 / 33(25 / 75)$ & $12 / 29(29 / 71)$ & & \\
\hline Urinary creatinine $/ 24 \mathrm{~h}, \mathrm{mmol}(\mathrm{n}=90)$ & $8.7(8.0-9.4)$ & $9.0(8.1-9.9)$ & $8.5(7.5-9.5)$ & & \\
\hline
\end{tabular}

CRP: C-reactive protein; GFR: glomerular filtration rate (as calculated by the Cockcroft and Gault equation); HbA1c: hemoglobin A1c; 25(OH)D: 25-hydroxyvitamin D; and PTH: parathyroid hormone. ${ }^{\text {Values expressed as }}$ mean $(95 \% \mathrm{CI})$, except where otherwise indicated.

femoral neck were higher in the patients with CFRD than in those without CFRD $(-1.73 ; 95 \% \mathrm{CI}:-1.74$ to -2.10 vs. $-2.30 ; 95 \% \mathrm{CI}:-1.90$ to $-2.69 ; \mathrm{p}=$ $0.003 ;$ OR $=0.13 ; 95 \% \mathrm{CI}: 0.02-0.67 ; \mathrm{p}=0.02$ ).

\section{DISCUSSION}

Low BMD is a common comorbidity in CF patients, ${ }^{(16)}$ affecting half of our cohort. This result is consistent with those of other studies ${ }^{(2,10,17)}$ and shows the high prevalence of bone disease in CF patients (and, in our particular cohort, in CF patients with end-stage lung disease undergoing LTx evaluation). Osteoporosis (particularly lumbar spine osteoporosis) was found to be more common in male CF patients than in female CF patients, as reported elsewhere. ${ }^{(18)}$

CF patients with end-stage lung disease are at a high risk of low BMD, and numerous cross-sectional studies have found a number of factors associated with low BMD, including lung function, BMI, and use of corticosteroids. ${ }^{(4-6,8,19-21)}$ With regard to age, there are conflicting results. $(2,3,6,17,19)$ In our cohort, the BMI was found to have a significant impact on BMD (particularly in patients evaluated later in the study period and at the femoral neck). However, no correlation was found between age and low BMD. Given that the BMI range was rather narrow in our cohort, this seems quite remarkable. Because we did not perform detailed body composition analysis, we were unable to determine whether there was a relationship between BMD and skeletal muscle mass or between BMD and fat mass. Decreased physical capacity ${ }^{(4,22)}$ and recurrent infections $^{(10,23)}$ are other known contributors to low BMD. In our cohort, neither exercise testing (6MWD) nor exacerbation frequency in the year before LTX evaluation correlated with low BMD. In addition, no correlation was found between low BMD and biochemical parameters. Vitamin D deficiency reflects malnutrition, affecting calcium homeostasis and bone turnover, ${ }^{(16)}$ being a common finding in patients with CF. Several studies have shown that $25(\mathrm{OH}) \mathrm{D}$ is low in patients with $\mathrm{CF}$, regardless of age. This is due to malabsorption, insufficient production of vitamin D in the skin (which is due to decreased exposure to sunlight as a result of lower levels of outdoor physical activity), lower amount of body fat for storage, decreased quantities of vitamin D-binding protein with a shorter half-life, and recurrent hospitalizations. ${ }^{(24)}$ Vitamin D deficiency can result in secondary hyperparathyroidism, and high PTH levels can be associated with low BMD in patients with CF. West et al. ${ }^{(25)}$ suggested that PTH is a more sensitive predictor of CFBD in CF patients than is $25(\mathrm{OH}) \mathrm{D}$. Although the majority of our patients showed $25(\mathrm{OH}) \mathrm{D}$ levels of $<30 \mu \mathrm{g} / \mathrm{L}$, there was no correlation of $25(\mathrm{OH}) \mathrm{D}$ with BMD or low BMD. In addition, there was no association of PTH levels with 

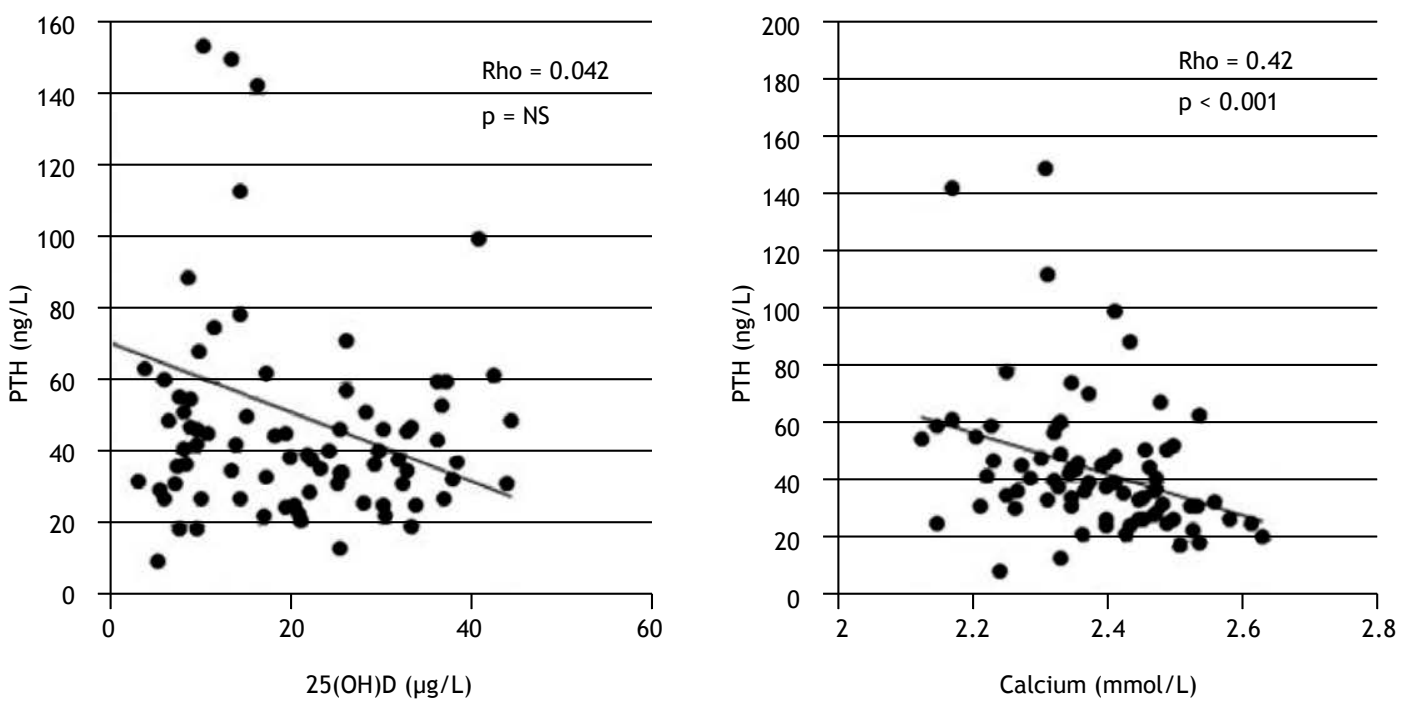

Figure 2. Spearman's correlation of serum parathyroid hormone (PTH) levels with serum 25-hydroxyvitamin D $(25(\mathrm{OH})$ D) and (albumin-corrected) calcium levels. NS: not significant.

$25(\mathrm{OH}) \mathrm{D}$ levels or low BMD in our patient cohort, a finding that is consistent with those of Flohr et al. ${ }^{(5)}$ It is of note that secondary hyperparathyroidism was found in only 13 patients in our cohort (PTH levels > $65 \mathrm{ng} / \mathrm{L})$. Neither decreased renal function nor low 25(OH)D levels led to increased PTH levels in the majority of our patients. In addition, PTH was found to be an inadequate parameter to detect or monitor CFBD; PTH levels did not reflect vitamin D deficiency in $\mathrm{CF}$ patients with end-stage lung disease and a high CFBD prevalence. However, the negative correlation between serum levels of albumin-corrected calcium and PTH was striking and highly significant. Almost $10 \%$ of the patients had borderline or elevated serum levels of albumin-corrected calcium; none had primary hyperparathyroidism. Osteocalcin, a serum marker of osteoblast activity, has been shown to correlate with bone loss. ${ }^{(26)}$ Changes in bone turnover with increased bone resorption and altered bone formation have been described elsewhere. ${ }^{(16,27,28)}$ However, we found no correlation of osteocalcin or deoxypyridinoline with BMD, having found only a borderline significant correlation with calciuria (as assessed in a fasting spot urine sample). Male hypogonadism has been shown to be associated with CFBD and vertebral fractures. ${ }^{(29,30)}$ Although the prevalence of low BMD was higher in males than in females in our cohort, we found no correlation between testosterone and BMD.

Experimental studies have shown that CFTR-null mice exhibit severe osteopenia. ${ }^{(31)}$ In a cross-sectional study including 88 adult patients with $C F$, it was reported that BMD at the lumbar spine and femoral neck is significantly lower in Phe508del homozygous or heterozygous patients than in patients without the $\triangle F 508$ mutation. ${ }^{(17)}$ Aris et al. ${ }^{(32)}$ speculated that CFTR mutations can provide a genetic link, directly influencing bone cell function. In addition, the CFTR protein has recently been shown to be expressed in human bone cells, playing an important role in the production of osteoprotegerin and prostaglandin E2, both of which are key factors in bone formation and regeneration. (33-35) Jacquot et al. tested a CFTR corrector (miglustat) in a Phe508del mutant CF mouse model, showing normalized bone volume and improved bone formation ${ }^{(11)}$ and raising the question of whether CFTR-targeted drugs can act directly on bone cells. In the present study, we found no correlation between the Phe508del mutation and CFBD. Although CFTR is expressed in bone tissue and therefore CF mutation status can theoretically influence bone mass density, our data clearly demonstrate that, in patients with end-stage lung disease, the lung disease itself and pancreatic insufficiency (leading to a catabolic metabolism) have in general a much broader indirect impact on bone health than does CFTR mutation status.

In the present study, the frequency of low BMD at the time of LTx evaluation decreased over time. Low BMD was found to be much more common in the earlier study period than in the later study period, a finding that is consistent with those of other studies. ( $^{(7,36,37)}$ Although this reduction in the incidence of low BMD was more pronounced at the femoral neck than at the lumbar spine, the latter became more severely affected over time than did the former. The patients who were evaluated for LTx later in the study period had a significantly higher BMI. In addition, vitamin D supplementation (alone or in combination with bisphosphonate therapy) was more common in those patients, whereas systemic corticosteroid therapy was less common. Accordingly, 25(OH)D levels tended to be higher in those patients. In addition, because CFRD was more frequently diagnosed in the later era than in the earlier era, insulin treatment was more common among the patients who were evaluated for LTx later in the study period than among those who were evaluated for LTx earlier in the study period, a finding that is consistent with those of another study. ${ }^{(38)}$ It is of note that BMD at the femoral neck was found to be 
significantly higher in patients with CFRD. Our findings are inconsistent with those of a recent study comparing patients with moderate CF evaluated in the 1995-1999 period and those evaluated in the 2011-2013 period, ${ }^{(39)}$ with no significant differences in BMD or BMI between the two cohorts of patients. Overall, the current practice for patients treated at our center has clearly led to a remarkable improvement in bone health. Our results indicate that awareness of CF as a "multiorgan disease", as well as a focus on improving nutrition and treating bone disease, together with early detection of CFRD and insulin treatment (systemic corticosteroid therapy being avoided), resulted in improved health (including bone health) and comorbidities that are less severe in our cohort of patients with CF.

Our study has several strengths. Our cohort consisted of CF patients with end-stage lung disease, thoroughly evaluated for LTx by using a standardized protocol. Therefore, our study provides detailed clinical information on a unique and well-studied cohort of patients, who were well-matched for lung function, performance status (6MWD), relative time to evaluation for LTX, and estimated 5-year survival. In comparison with other studies with similar sample size, ours involved a fairly homogenous cohort of patients with regard to lung disease severity. Evaluation of patients at a single center allows direct comparison of BMD values over a long observation period (i.e., nearly two decades), given that DXA machines were calibrated accordingly.

One limitation of our study is that DXA results were reported as T-scores. Z-scores were not available for most of the patients evaluated earlier in the study period. For reasons of comparability, data on the entire cohort were reported as T-scores. Given that the study patients were in the 25- to 30-year age bracket, T-scores were not expected to result in major data distortion.

CFBD is a common comorbidity in patients with CF and can have a severe impact on health status and health-related quality of life. The development and progression of CF clinical manifestations such as CFBD are mainly determined by environmental exposure, medical treatment, and therapy adherence, as well as CFTR mutation status. The prevalence of low BMD in CF lung transplant candidates has decreased in recent years, indicating a better understanding of $\mathrm{CF}$ as a multiorgan disease and improved multidisciplinary CF care, including early screening and treatment of CF-related comorbidities. In the present study, we found no correlation between CFTR mutation status and CFBD. In our opinion, lung disease severity and pancreatic insufficiency have a much broader (indirect) impact on the development of CFBD than does CFTR mutation status per se.

Overall, we were unable to identify a biochemical parameter associated with CFBD in CF patients with end-stage lung disease (with the possible exception of fasting calciuria, reflecting net bone loss). DXA remains the only reliable diagnostic tool to evaluate CFBD, which is still a prevalent and challenging problem, especially in patients with advanced lung disease, male patients, and patients with low BMI. In the last decade, efforts have been made to prevent and treat CFBD accordingly. Our data show that our current practice in managing patients with CFBD has lead to improved bone health.

\section{REFERENCES}

1. Stoltz DA, Meyerholz DK, Welsh MJ. Origins of cystic fibrosis lung disease. N Engl J Med. 2015;372(16):1574-5. https://doi.org/10.1056/ NEJMc1502191

2. Paccou J, Zeboulon N, Combescure C, Gossec L, Cortet B. The prevalence of osteoporosis, osteopenia, and fractures among adults with cystic fibrosis: a systematic literature review with metaanalysis. Calcif Tissue Int. 2010;86(1):1-7. https://doi.org/10.1007/ s00223-009-9316-9

3. Conway SP, Morton AM, Oldroyd B, Truscott JG, White H, Smith $\mathrm{AH}$, et al. Osteoporosis and osteopenia in adults and adolescents with cystic fibrosis: prevalence and associated factors. Thorax. 2000;55(9):798-804. https://doi.org/10.1136/thorax.55.9.798

4. Elkin SL, Fairney A, Burnett S, Kemp M, Kyd P, Burgess J, et al. Vertebral deformities and low bone mineral density in adults with cystic fibrosis: a cross-sectional study. Osteoporos Int. 2001;12(5):366-72. https://doi.org/10.1007/s001980170104

5. Flohr F, Lutz A, App EM, Matthys $H$, Reincke M. Bone mineral density and quantitative ultrasound in adults with cystic fibrosis. Eur J Endocrinol. 2002;146(4):531-6. https://doi.org/10.1530/ eje.0.1460531

6. Rossini M, Del Marco A, Dal Santo F, Gatti D, Braggion C, James G, et al. Prevalence and correlates of vertebral fractures in adults with cystic fibrosis. Bone. 2004;35(3):771-6. https://doi.org/10.1016/j. bone.2004.05.009

7. Grey V, Atkinson S, Drury D, Casey L, Ferland G, Gundberg C, et al. Prevalence of low bone mass and deficiencies of vitamins $D$ and $\mathrm{K}$ in pediatric patients with cystic fibrosis from 3 Canadian centers. Pediatrics. 2008;122(5):1014-20. https://doi.org/10.1542/peds.20072336

8. Legroux-Gérot I, Leroy S, Prudhomme C, Perez T, Flipo RM, Wallaert $\mathrm{B}$, et al. Bone loss in adults with cystic fibrosis: prevalence, associated factors, and usefulness of biological markers. Joint Bone Spine. 2012;79(1):73-7. https://doi.org/10.1016/j.jbspin.2011.05.009

9. Tschopp O, Boehler A, Speich R, Weder W, Seifert B, Russ EW, et al. Osteoporosis before lung transplantation: association with low body mass index, but not with underlying disease. Am J Transplant. 2002;2(2):167-72. https://doi.org/10.1034/j.16006143.2002.020208.x

10. Ionescu AA, Nixon LS, Evans WD, Stone MD, Lewis-Jenkins $V$, Chatham K, et al. Bone density, body composition, and inflammatory status in cystic fibrosis. Am J Respir Crit Care Med. 2000;162/3 Pt 1):789-94. https://doi.org/10.1164/ajrccm.162.3.9910118

11. Jacquot J, Delion M, Gangloff S, Braux J, Velard F. Bone disease in cystic fibrosis: new pathogenic insights opening novel therapies. Osteoporos Int. 2016;27(4):1401-1412. https://doi.org/10.1007/ s00198-015-3343-3

12. Orens JB, Estenne M, Arcasoy S, Conte JV, Corris P, Egan JJ, et al. International guidelines for the selection of lung transplant candidates: 2006 update-a consensus report from the Pulmonary Scientific Council of the International Society for Heart and Lung Transplantation. J Heart Lung Transplant. 2006;25(7):745-55. https:// doi.org/10.1016/j.healun.2006.03.011

13. Liou TG, Adler FR, Fitzsimmons SC, Cahill BC, Hibbs JR, Marshall BC. Predictive 5-year survivorship model of cystic fibrosis. Am J Epidemiol. 2001;153(4):345-52. https://doi.org/10.1093/aje/153.4.345

14. Soulsby N, Greville H, Coulthard K, Doecke C. What is the best method for measuring renal function in adults and children with cystic fibrosis? J Cyst Fibros. 2010;9(2):124-9. https://doi.org/10.1016/j. jcf.2009.12.002

15. Dimai HP. Use of dual-energy X-ray absorptiometry (DXA) for diagnosis and fracture risk assessment; WHO-criteria, T- and Z-score, and reference databases. Bone. 2017;104:39-43. https://doi. 
org/10.1016/j.bone.2016.12.016

16. Aris RM, Ontjes DA, Buell HE, Blackwood AD, Lark RK, Caminiti M, et al. Abnormal bone turnover in cystic fibrosis adults. Osteoporos Int. 2002;13(2):151-7. https://doi.org/10.1007/s001980200007

17. King SJ, Topliss DJ, Kotsimbos T, Nyulasi IB, Bailey M, Ebeling PR, et al. Reduced bone density in cystic fibrosis: DeltaF508 mutation is an independent risk factor. Eur Respir J. 2005;25(1):54-61. https://doi.or $\mathrm{g} / 10.1183 / 09031936.04 .00050204$

18. Baker JF, Putman MS, Herlyn K, Tillotson AP, Finkelstein JS, Merke PA. Body composition, lung function, and prevalent and progressive bone deficits among adults with cystic fibrosis. Joint Bone Spine. 2016;83(2):207-11. https://doi.org/10.1016/j.jbspin.2015.04.021

19. Laursen EM, Molgaard C, Michaelsen KF, Koch C, Müller J. Bone mineral status in 134 patients with cystic fibrosis. Arch Dis Child. 1999:81(3):235-40. https://doi.org/10.1136/adc.81.3.235

20. Gronowitz E, Garemo M, Lindblad A, Mellström D, Strandvik B. Decreased bone mineral density in normal-growing patients with cystic fibrosis. Acta Paediatr. 2003;92(6):688-93. https://doi. org/10.1111/j.1651-2227.2003.tb00601.x

21. Grey AB, Ames RW, Matthews RD, Reid IR. Bone mineral density and body composition in adult patients with cystic fibrosis. Thorax. 1993;48(6):589-93. https://doi.org/10.1136/thx.48.6.589

22. Frangolias DD, Holloway CL, Vedal S, Wilcox PG. Role of exercise and lung function in predicting work status in cystic fibrosis. Am J Resp Crit Care. 2003;167(2):150-7. https://doi.org/10.1164/rccm.2202053

23. Shead E, Haworth C, Barker H, Gunn E, Bilton D, Scott M, et al. Alterations in bone metabolism occur at times of infective exacerbation in adults with cystic fibrosis. Thorax. 2006;61:li35-li.

24. Javier RM, Jacquot J. Bone disease in cystic fibrosis: what's new? Joint Bone Spine. 2011;78(5):445-50. https://doi.org/10.1016/1. jbspin.2010.11.015

25. West NE, Lechtzin N, Merlo CA, Turowski JB, Davis ME, Ramsay MZ, et al. Appropriate goal level for 25-hydroxyvitamin D in cystic fibrosis. Chest. 2011;140(2):469-474. https://doi.org/10.1378/ chest.10-2114

26. Prummel MF, Wiersinga WM, Lips P, Sanders GT, Sauerwein HP. The course of biochemical parameters of bone turnove during treatment with corticosteroids. J Clin Endocrinol Metab. 1991;72(2):382-6. https://doi.org/10.1210/jcem-72-2-382

27. Gordon CM, Binello E, LeBoff MS, Wohl ME, Rosen CJ Colin AA. Relationship between insulin-like growth factor I, dehydroepiandrosterone sulfate and proresorptive cytokines and bone density in cystic fibrosis. Osteoporos Int. 2006;17(5):783-90. https://doi.org/10.1007/s00198-005-0058-x

28. Aris RM, Merkel PA, Bachrach LK, Borowitz DS, Boyle MP, Elkin $\mathrm{SL}$, et al. Guide to bone health and disease in cystic fibrosis. J Clin
Endocrinol Metab. 2005;90(3):1888-96. https://doi.org/10.1210/ jc. 2004-1629

29. Donovan DS Jr, Papadopoulos A, Staron RB, Addesso V, Schulman $L$, McGregor $C$, et al. Bone mass and vitamin $D$ deficiency in adults with advanced cystic fibrosis lung disease. Am J Respi Crit Care Med. 1998;157(6 Pt 1):1892-9. https://doi.org/10.1164/ ajrccm.157.6.9712089

30. Leifke E, Friemert M, Heilmann M, Puvogel N, Smaczny C, von zur Muhlen $\mathrm{A}$, et al. Sex steroids and body composition in men with cystic fibrosis. Eur J Endocrinol. 2003;148(5):551-7. https://doi. org/10.1530/eje.0.1480551

31. Dif F, Marty C, Baudoin C, de Vernejoul MC, Levi G. Severe osteopenia in CFTR-null mice. Bone. 2004;35(3):595-603. https://doi. org/10.1016/j.bone.2004.05.021

32. Aris RM, Guise TA. Cystic fibrosis and bone disease: are we missing a genetic link? Eur Respir J. 2005;25(1):9-11. https://doi.org/10.1183 109031936.04.00125804

33. Le Heron L, Guillaume C, Velard F, Braux J, Touqui L, Moriceau S, et al. Cystic fibrosis transmembrane conductance regulator (CFTR) regulates the production of osteoprotegerin (OPG) and prostaglandin (PG) E2 in human bone. J Cyst Fibros. 2010;9(1):69-72. https://doi. org/10.1016/i.jcf.2009.11.005

34. Shead EF, Haworth CS, Condliffe AM, McKeon DJ, Scott MA, Compston JE. Cystic fibrosis transmembrane conductance regulator (CFTR) is expressed in human bone. Thorax. 2007;62(7):650-1. https://doi.org/10.1136/thx.2006.075887

35. Gimenez-Maitre A, Le Henaff C, Norez C, Guillaume C, Ravoninjatovo $B$, Laurent-Maquin $D$, et al. Deficit of osteoprotegerin release by osteoblasts from a patient with cystic fibrosis. Eur Respir $\mathrm{J}$. 2012;39(3):780-1. https://doi.org/10.1183/09031936.00104111

36. Le Henaff C, Haÿ E, Velard F, Marty C, Tabary O, Marie PJ, et al. Enhanced F508del-CFTR channel activity ameliorates bone pathology in murine cystic fibrosis. Am J Pathol. 2014;184(4):11321141. https://doi.org/10.1016/j.ajpath.2013.12.027

37. Stephenson A, Jamal S, Dowdell T, Pearce D, Corey M, Tullis E. Prevalence of vertebral fractures in adults with cystic fibrosis and their relationship to bone mineral density. Chest. 2006;130(2):53944. https://doi.org/10.1378/chest.130.2.539

38. Hofer M, Schmid C, Benden C, Speich R, Inci I, Weder W, et al. Diabetes mellitus and survival in cystic fibrosis patients after lung transplantation. J Cyst Fibros. 2012;11(2):131-6. https://doi. org/10.1016/j.jcf.2011.10.005

39. Putman MS, Baker JF, Uluer A, Herlyn K, Lapey A, Sicilian L, et al. Trends in bone mineral density in young adults with cystic fibrosis over a 15 year period. J Cyst Fibros. 2015;14(4):526-32. https://doi. org/10.1016/.j.jcf.2015.01.011 